\title{
Pengaruh Pertumbuhan Ekonomi dan Rata-Rata Lama Sekolah Terhadap Kemiskinan Di Provinsi Jawa Tengah
}

\author{
Miftaqh Nur Faritz \\ Program Studi Pendidikan Ekonomi, Fakultas Ekonomi, Universitas Negeri Surabaya \\ email: miftaqhfaritz16080554052@mhs.unesa.ac.id \\ Ady Soejoto \\ Program Studi Pendidikan Ekonomi, Fakultas Ekonomi, Universitas Negeri Surabaya \\ email: $\underline{\text { adysfe@yahoo,co.id }}$
}

\begin{abstract}
Abstrak
Latar belakang yang mendasari penelitian ini karena Provinsi Jawa Tengah merupakan provinsi dengan presentase penduduk miskin sebesar 11,19\% Tahun 2018 dan menempati posisi dua terbawah dari berberapa provinsi yang ada di Pulau Jawa, Kemiskinan di Jawa Tengah disebabkan oleh rendahnya pertumbuhan ekonomi serta rendahnya pendidikan masyarakat. Tujuan penelitian ini untuk mengetahui pengaruh pertumbuhan ekonomi dan rata-rata lama sekolah terhadap kemiskinan di Provinsi Jawa Tengah. Penelitian ini menggunakan teknik analisis data panel dengan data yang diperoleh dari Badan Pusat Statistik, mengunakan Cross Section 35 kabupaten/kota di Provinsi Jawa Tengah dan Time Series tahun 2009-2018, menggunakan model random effect. Hasil dari penelitian ini menunjukkan bahwa secara parsial pertumbuhan ekonomi berpengaruh signifikan negatif terhadap kemiskinan di provinsi jawa tengah, rata-rata lama sekolah berpengaruh signifikan negatif terhadap kemiskinan di provinsi jawa tengah. Sedangkan secara simultan pertumbuhan ekonomi dan rata-rata lama sekolah berpengaruh signifikan negatif terhadap kemiskinan di provinsi jawa tengah
\end{abstract}

Kata Kunci : Pertumbuhan Ekonomi. Rata-Rata Lama Sekolah dan Kemiskinan

\section{Abstract}

The background which is the basis of this research is that Central Java Province is a province with a poor population percentage of $11.19 \%$ in 2018 and occupies the second lowest position of several provinces in Java Island, Poverty in Central Java is caused by low economic growth and low public education. The purpose of this study was to determine the effect of economic growth and average length of school on poverty in Central Java Province. This research uses panel data analysis techniques with data obtained from the Central Statistics Agency, using Cross Section 35 districts / cities in Central Java Province and Time Series in 2009-2018, using a random effect model. The results of this research show that partially economic growth has a significant negative effect on poverty in Central Java Province, the average length of school has a significant negative effect on poverty in the province of Central Java. While simultaneous economic growth and average length of school have a significant negative effect on poverty in Central Java Province.

Keywords: Economic Growth, Mean Years School, Poverty.

\section{PENDAHULUAN}

Permasalahan kemiskinan bukan permasalahan nasional saja tertapi juga masalah tiap-tiap daerah, diantara daerah di Indonesia dengan angka kemiskinanya cukup tinggi ialah Provinsi Jawa Tengah, dengan angka kemiskinan di kabupaten dan kota dengan angka 11,32\% tahun 2018. Penigkatan pertumbuhan di sektor ekonomi dan pendidikan adalah faktor utama dalam menurunkan presentase penduduk miskin, berdasarkan teori trickledown effect Hirschman (1958) pertumbuhan ekonomi berdampak dalam upaya pengentasan kemiskinan. Pertumbuhan ekonomi adalah pokok atau kunci pemerintah dalam menurunkan angka penduduk miskin, pemerintah menggunakan tolak ukur pertumbuhan ekonomi sebagai cermin dari berbagai program pembangunan ekonomi dan syarat utama guna mengurangi angka kemiskinan di Jawa Tengah. Hasil penelitian yang oleh Mills \& Perenia (1993) menyatakan kemiskinan akan mengalami penurunan saat pertumbuhan ekonomi tahun sebelumnya naik, apabila pertumbuhan PDB mengalami peningkatan terus menerus angka kemiskinan akan turun, teori ekonomi neo klasik menyatakan bahwa berpendapat bahwa PDRB adalah tolak ukur pertumbuhan ekonomi di daerah.

Faktor lain yang berperan dalam pengentasan kemiskinan adalah peningkatan di bidang pendidikan, menurut Cooray (2009) masyarakat berpendidikan tinggi 
akan membawa pada pertumbuhan ekonomi yang lebih tinggi, sehingga mempermudah pemerintah mengatasi kemiskinan, pendidikan dan pertumbuhan ekonomi terdapat hubungan yang dapat dijelaskan melalui teori human capital. Indikator pendidikan dalam penghitungan IPM metode baru dapat diukur melalui angka melek huruf (AMH) serta rata-rata lama sekolah (RLS). RLS Menggambarkan jumlah tahun penduduk mengenyam pendidikan formal. Menurut teori human capital modal di bidang pendidikan akan menghasilkan lulusan yang memiliki produktifitas tinggi, Semakin tinggi maka semakin baik kualitasnya. pendidikan dapat membuat seseorang keluar dari lingkaran kemiskinan. Berdasarkan uraian diatas, maka peneliti ingin mencari pengaruh pertumbuhan ekonomi dan pendidikan terhadap kemiskinan di Provinsi Jawa Tengah.

Definisi secara umum yang sering dipergunakan dalam perhitungan dan kajian-kajian akademik adalah definisi kemiskinan yang diperkenalkan oleh Bank Dunia yaitu sebagai ketidakmampuan dalam mencapai standar kehidupan yang minimum Bank (1990) Dalam laporannya di hadapan anggota PBB yang bertema "Poverty and Human Development" mengatakan bahwa, pembangunan manusia tidak hanya diutamakan pada aspek ekonomi, tapi yang lebih penting ialah mengutamakan aspek pendidikan secara universal bagi kepentingan diri orang miskin guna meningkatkan kehidupan sosial ekonominya, Menurut Nasution, Z. dan Hartono (2007) terdapat beberapa faktor penyebab kemiskinan, yakni (1) Rendahnya pendidikan, (2) Malas bekerja, (3) Keterbatasan sumber alam, (4) Keterbatasan lapangan kerja, (5) Keterbatasan modal dan, (6) beban keluarga.

Menurut BPS (2008) berpebdapat bahwa terdapat 3 indikator kemiskinan yang dilihat dari pendekatan kebutuhan dasar yaitu: presentase, kedalaman dan keparahan kemiskinan. Peneliti menggunakan indikator persentase penduduk miskin (HCI-P0) didalam penelitianya, Headcount Index secara bertujuan mengukur presentase penduduk miskin, yang data berasal dari hasil survey nasional (SUSENAS) tahunan. CMenurut Sastraatmadja E (2003) pola kemiskinan ada 4 jenis yaitu (1) Persistent proverty, (2) Cyclical proverty, (3) Seasonal proverty, (4) Accidental proventy, Kemiskinan di Jawa Tengah masuk kedalam cyclical proverty, dikarenakan kemiskinan di Provinsi Jawa Tengah terus mengalami perubahan ke arah yang lebih baik, buk an karena berubah sendiri, tetapi karena dipengaruhi oleh siklus/keadaan ekonomi saat itu, seperti faktor pengangguran, pertumbuhan ekonomi, pendidikan dan lain-lain, jika berberapa faktor diatas mengalami kenaikan ataupun penurunan maka juga akan berdampak pada kemiskinan. Berdasarkan hasil penelitian yang dilakukan oleh Wahyudi \& Rejeningsih (2013) bahwa kemiskinan di
Provinsi Jawa Tengah dipengaruhi oleh faktor Kesehatan, pendidikan, pengeluaran pemerintah, pertumbuhan ekonomi dan pengangguran, dalam hasil penelitianya menyebutkan bahwa 94,2\% kemiskinan dipengaruhi oleh berberapa faktor diatas. Adapun sektor yang berperan dalam pengentasan kemiskinan di tahun 2018 menurut informasi yang dimuat dalam berita tempo.co, tribunjateg menyebutkan bahwa yaitu (1) UMKM, (2) program subsidi, ((3) peningkatan UMK.

Peneliti menggunakan indikator persentase penduduk miskin (HCI-P0) didalam penelitianya, Headcount Index secara bertujuan mengukur presentase penduduk miskin, yang data berasal dari hasil survey nasional (SUSENAS) tahunan, Teori tersebut mengimplikasikan bahwa pertumbuhan ekonomi akan diikuti oleh aliran vertikal dari penduduk kaya ke penduduk miskin yang terjadi dengan sendirinya, sehingga manfaat pertumbuhan ekonomi secara tidak langsung akan berdampak pada penurunan kemiskinan.

Teori ekonomi neo klasik menyatakan bahwa berpendapat bahwa PDRB adalah tolak ukur pertumbuhan ekonomi di daerah. Menurut badan pusat statistik laju pertumbuhan ekonomi adalah meningkatnya produk domestik bruto harga konstan (riil) secara keseluruhan sektor ekonomi dari tahun ke tahun, sama halnya dengan laju pertumbuhan ekonomi negara, adapun laju pertumbuhan ekonomi daerah bisa diperoleh dari nilai PDRB, Indikator yang dipakai pada variabel pertumbuhan ekonomi. Pada penelitian ini adalah laju pertumbuhan ekonomi kabupaten kota di Provinsi Jawa Tengah yang didasarkan pada PDRB Provinsi Jawa Tengah periode tahun 2009-2018. Pertumbuhan ekonomi yaitu kegiatan ekonomi yang bertujuan meningkatkan produksi barang dan jasa di masyrakat, jadi jika pertumbuhan ekonomi naik akan di ikuti dengan peningkatan barang dan jasa dengan ini kesejahteraan akan meningkat Sukirno (2012).

Menurut Sukirno (2011) dilihat dari sudut pandang ekonom klasik, empat faktor yang turut memiliki pengaruh dengan pertumbuhan ekonomi, antara lain (1) Jumlah dan kualitas penduduk (SDM). (2) Ketersediaan dan kecukupan modal, (3) Luas wilayah dan ketersediaan sumber daya, (4) Penguasaan dan kemajuan teknologi. Berdasarkan informasi yang didapat dari tempo.co, tribunjateng.com, bisnis.com serta publikasi dari bank indonesia menyebutkan bahwa pertumbuhan ekonomi di Jawa Tengah pada tahun 2018-2019 terus mengalami peningkatan yang sangat signifikan dibandingkan tahun sebelumnya, adapun sektor/program yang menunjang dan akan menunjang pertumbuhan ekonomi yaitu (1) peningkatan UMKM , (2) pertumbuhan lapangan industri pertanian perhutanan, (3) pengembangan kawasan industri brebes dan kendal, (4) penguatan kegiatan ekspor dan meminimalkan kegiatan impor. 
Teori modal manusia yang dikemukakan becker (1964) dalam bukunya "human capital" menjelaskan bahwa pendidikan dinilai memiliki peranan penting dalam kemiskinan dan pertumbuhan ekonomi, seperti dalam tulisanya yaitu manusia yang mengenyam pendidikan tinggi maka akan mendapatkan pekerjaan serta upah yang lebih layak, serta dapat menghindarkan manusia dari kemiskinan. Menurut keterangan Badan Pusat Statistik (BPS), Indeks Pembangunan Manusia (IPM) adalah salah satu indikator yang digunakan untuk mengukur keberhasilan pembangunan. Salah satu aspek dalam IPM yang dapat dijadikan bahan evaluasi ternadap peningkatan kualitas sumber daya manusia di suaru negara adalah indeks pendidikan. Dalam IPM metode baru cara untuk mengukur pendidikan masyarakat adalah dengan melihat harapan lama sekolah dan Mean Years School/Rata-rata lama sekolah. Rata-Rata Lama Sekolah (RLS) adalah ratarata jumlah tahun yang telah diselesaikan oleh penduduk pada seluruh jenjang pendidikan formal yang pernah dijalani. Menurut Mankiw \& Gregory (2012) pendidikan merupakan bentuk investasi individu, di mana jika semakin tinggi pendidikan, maka kesejahteraan suatu individu akan meningkat dan hal ini juga akan mempengaruhi kesejahteraan ekonomi suatu negara dalam jangka panjang.

Menurut UU. No.20 (2003) pasal 3 tentang sistem pendidikan nasional, tujuan pendidikan nasional adalah membuat kemampuan peserta didik berkembang agar menjadi manusia beriman dan percaya kepada Tuhan Yang Maha Esa, berilmu dan menjadi warga negara yang demokratis serta bertanggung jawab. Program dibidang pendidikan merupakan aspek yang penting dalam keberhasilan di bidang pendidikan. Pemerintah provinsi jawa tengah telah menyiapkan berbagai program pendidikan untuk meringankan masyarakat khususnya masyarakat miskin diantaranya dengan berberapa program yang akan di jalankan di tahun 2020, sebuah program yang bertujuan untuk meningkatkan kualitas dan kuantitas pendidikan, karena diketahui kondisi pendidikan di provinsi jawa tengah berada diposisi bawah diantara provinsi lain di pulau jawa.

Adapun programnya yang diharapkan mampu mengurangi presentase penduduk miskin di jawa tengah yakni (1) Peningkatan anggaran pendidikan, (2) Program sekolah gratis bagi siswa SMA/SMK dan SLB Negeri, (3) Pengawasan pencegahan pungutan liar di lingkup pendidikan, (4) Guru honorer dan pegawai tidak tetap akan diberikan gaji sesuai dengan UMK menurut informasi (ID TIMES). Perbaikan infrastruktur dan sarana prasarana sekolah juga tak lepas dari sorotan pemerintah provinsi jawa tengah, dimana program yang rencananya akan di prioritaskan dibidang pendidikan juga termasuk infrastruktur dan sarana prasarana sekolah.
Berdasarkan uraian diatas, maka peneliti ingin meneliti pengaruh pertumbuhan ekonomi dan rata-rata Lama sekolah terhadap kemiskinan di Provinsi Jawa Tengah tahun 2008-2019

\section{METODE}

Penelitian ini adalah penelitian kuantitatif asosiatif, menurut Sugiyono (2014) penelitian ini mencari hubungan atau pengaruh satu atau dua variable terhadap variable dependent, penelitian ini mencari pengaruh pertumbuhan ekonomi dan rata-rata lama sekolah terhadap kemiskinan di provinsi jawa tengah, Populasi dalam penelitian ini adalah seluruh data tingkat pertumbuhan ekonomi, pendidikan dan kemiskinan di Provinsi Jawa Tengah tahun 2009-2018. Dengan jenis sampel yang digunakan dalam penelitian ini adalah sampel jenuh yakni semua anggota populasi yaitu (PDRB), rata-rata lama sekolah (RLS/MYS) dan kemiskinan (Head Count Index) di 35 kabupaten dan kota se Provinsi Jawa Tengah. Teknik pengumpulan data yang digunakan dalam penelitian ini adalah dengan mengambil data dari badan pusat statistik/data sekunder, data sekunder adalah merupakan data diambil dari suatu instansi/lembaga yang berhubungan dengan penelitian Sumarsono (2004) data sekunder yang dikumpulkan untuk penelitian ini meliputi data tentang pertumbuhan ekonomi, rata-rata lama sekolah dan kemiskinan dari tahun 2009-2018.

Teknik analisis data yang digunakan dalam penelitian ini adalah data panel, yaitu kombinasi antara data silang (cross section) dan data runtut waktu (time series) menurut Kuncoro (2011). maka teknik analisa data yang digunakan adalah menggunakan aplikasi statistika EVIEWS 9. Data panel dapat dicari estimasinya dengan 3 metode pendekatan menurut Basuki \& Prawoto (2016) yaitu: (1) common effect model, (2) fix effect model, (random effect model, maka tahap berikutnya adalah menentukan estimasi yang cocok dengan melakukan uji Chow, Hausman dan Langrange Multiplier (LM). Uji LM diperlukan apabila dengan uji Chow model yang terpilih adalah fixed effect dan uji Hausman model yang terpilih yaitu random effect. Apabila pada uji Chow dan Hausman model yang terpilih fixed effect, uji LM tidak perlu dilakukan. Setelah diketahui estimasi mana yang terpilih dalam penelitian maka langkah selanjutnya yaitu melakukan uji hipotesis yang dilakukan dengan 3 macam uji yaitu : (1) Uji Koefisien Determinasi, (2) Uji F/Uji Simultan, (3) uji T/Uji parsial.

\section{HASIL DAN PEMBAHASAN Hasil}

Hasil uji chow dalam menentukan antara model common effect atau model fix effect 
Table 1.1 Tabel Hasil Uji Chow

\begin{tabular}{|c|c|c|c|}
\hline Effects Test & Statistic & Prob & sign 5\% \\
\hline Cross-section F & 49.147489 & 0.0000 & 0,05 \\
\hline Chi-square & 646.336062 & 0.0000 & 0,05 \\
\hline
\end{tabular}

Sumber : data diolah dengan eviwes 9, tahun 2019

Hasil uji chow di atas didapat probabilitas untuk uji f dan chi square sebesar $0.0000<0,05$, artinya menolak H0, sehingga metode yang paling cocok digunakan adalah fixed effect

Hasil uji hausman dalam menentukan antara model fix effect atau model random effect

Table 1.2 Tabel Hasil Uji Hausman

\begin{tabular}{|c|c|c|l|l|}
\hline Test Summary & $\begin{array}{c}\text { Chi-Sq. } \\
\text { Statistic }\end{array}$ & $\begin{array}{c}\text { Chi-Sq. } \\
\text { d.f. }\end{array}$ & prob & $\begin{array}{l}\text { sign } \\
5 \%\end{array}$ \\
\hline $\begin{array}{c}\text { Cross-section } \\
\text { random }\end{array}$ & 1.232464 & 2 & 0.5400 & 0,05 \\
\hline
\end{tabular}

Sumber : data diolah dengan eviwes 9, tahun 2019

Hasil uji di atas didapat probabilitas cross section sebesar $0.5400>0,05$, artinya uji hausman menolak hipotesis H1, sehingga metode yang paling cocok digunakan adalah random effect

Hasil lagrange multipliers dalam menentukan antara model random effect atau model common effect

Table 1.3 Tabel Hasil Uji Lagrange Multipliers

\begin{tabular}{|c|c|c|c|}
\hline Test Summary & Cross-section & Time & Both \\
\hline Breusch- & 1063.517 & 46.18814 & 1109.705 \\
Pagan & $(0.0000)$ & $(0.0000)$ & $(0.0000)$ \\
& & & \\
\hline
\end{tabular}

Sumber : data diolah dengan eviwes 9, tahun 2019

Hasil uji di atas didapat $p$ value untuk uji $f$ dan chi square sebesar $0.0000<0,05$, artinya menolak $\mathrm{H} 1$, sehingga metode yang paling cocok digunakan adalah random effect

Uji hipotesis koefisien determinasi, Menurut Ghozali (2013) koefisien determinasi digunakan untuk melihat presentase sumbangan pengaruh kedua variable bebas terhadap variable terikat. Jika nilai kecil maka variable bebas terbatas dalam menjelaskan variable terikat, dan jika nilainya mendekati 1 (satu) maka variable bebas lebih luas/informatif dalam menjelaskan variable terikat, untuk melihat hasil uji Koefisien Determinasi maka dilihat pada outpun model terpilih dengan melihat skor pada R-square.

\begin{tabular}{|c|c|}
\hline Weighted Statistics & Skor \\
\hline R-squared & 0.308874 \\
\hline Adjusted R-squared & 0.304890 \\
\hline S.E. of regression & 1.567254 \\
\hline
\end{tabular}

Berdasarkan nilai R-squared dari output model random effect model sebesar 0,308874, maka dapat disimpulkan bahwa $30,8 \%$ kemiskinan di provinsi jawa tengah disebabkan oleh pertumbuhan ekonomi dan rata-rata lama sekolah, sedangkan 69,2\% kemiskinan dipengaruhi oleh factor-faktor lain.
Uji F (simultan) pada digunakan untuk melihat apakah semua variable independent yang digunakan peneliti terdapat pengaruh bersama terhadap variablee dependent Ghozali (2013) Uji F ini dilihat dari nilai signifikansi, adapun hasil uji hipotesis uji $F$ pada penelitian ini dapat dilihat pada table dibawah ini.

Table 1.4 Tabel Uji F

\begin{tabular}{|c|c|c|}
\hline Weighted Statistics & Skor & sign 5\% \\
\hline F-statistic & 77.53949 & 0,05 \\
\hline Prob(F-statistic) & 0.000000 & 0,05 \\
\hline
\end{tabular}

Sumber : data diolah dengan eviwes 9, tahun 2019

Berdasarkan table diatas diketahui probability $\mathrm{F}$ statistik memiliki nilai 0,0000 lebih kecil dibandingkan 0,05 atau taraf kesalahan 5\%, hal ini membuktikan bahwa variable pertumbuhan ekonomi dan rata-rata lamna sekolah berpengaruh signifikan terhadap kemiskinan di provinsi jawa tengah.

Uji T dilakukan untuk melihat pengaruh salah satu variable bebas/independen terhadap variable terikat /dependent Ghozali (2013), adapun hasil uji hipotesis uji $\mathrm{T}$ pada penelitian ini dapat dilihat pada bagian probabilitas pada output model terpilih random effect model seperti table dibawah ini

Table 1.7 Tabel Uji T

\begin{tabular}{|c|c|c|c|}
\hline Variabel & Koefisien regresi & Prob & $\begin{array}{c}\text { sign } \\
5 \%\end{array}$ \\
\hline $\begin{array}{c}\text { Pertumbuhan } \\
\text { ekonomi (x1) }\end{array}$ & -0.210931 & 0.0052 & $5 \%$ \\
\hline $\begin{array}{c}\text { rata-rata lama } \\
\text { sekolah (x2) }\end{array}$ & -2.702 .084 & 0.0000 & $5 \%$ \\
\hline
\end{tabular}

Sumber : data diolah dengan eviwes 9, tahun 2019

Berdasarkan uji $\mathrm{T}$ didapatkan bahwa variable pertumbuhan ekonomi memiliki probabilitas sebesar 0,0052 lebih kecil disbanding 0,05 atau taraf kesalahan $5 \%$, yang berarti variable berpengaruh signifikan dan koefisien regresi -0.210931 yang berarti pertumbuhan ekonomi dan kemiskinan berhubungan negatif. Berdasarkan uji $\mathrm{T}$ didapatkan bahwa variable rata-rata lama sekolah memiliki probabilitas sebesar 0,0000 lebih kecil disbanding 0,05 atau taraf kesalahan 5\%, yang berarti variable berpengaruh signifikan dan koefisien regresi -2.702.084 yang berarti rata-rata lama sekolah dan kemiskinan berhubungan negative.

\section{Pembahasan}

\section{Koefisien Determinasi Pengaruh Pertumbuhan Ekonomi dan Rata-Rata Lama Sekolah Terhadap Kemiskinan di Provinsi Jawa Tengah tahun 2009. 2018}

Hasil yang diperoleh dari uji hipotesis pertama yaitu uji koefisien determinasi, yaitu uji yang dilaukan untuk mengukur presentase kedua variable yaitu 
pertumbuhan ekonomi dan rata-rata lama sekolah terhadap variable $\mathrm{Y}$ yaitu kemiskinan di provinsi jawa tengah. Hasil regresi uji korfisien determinasi didapatkan $R$-squared sebesar 0.308874. yang dapat dilihat pada output random effect. Dengan demikian maka diketahui sebesar 30,8\%, variable kemiskinan dapat dijelaskan oleh variasi variable independent, yaitu pertumbuhan ekonomi dan rata-rata lama sekolah, sedangkan 69,2\% dijelaskan variable lain pada tahun 2009-2018. Penelitian ini didukung oleh jurnal penelitian yang dilakukan oleh Wahyudi \& Rejekingsih, bahwa didapatkan nilai R-square sebesar 0,94200, dengan demikian bahwa 94,2\% kemiskinan di jawa tengah dipengaruhi oleh faktor kesehatan, pendidikan, pengeluaran pemerintah, pertumbuhan ekonomi dan penganggan.

Pengaruh Pertumbuhan Ekonomi dan Rata-Rata Lama Sekolah Terhadap Kemiskinan di Provinsi Jawa Tengah tahun 2009-2018

Berdasarkan hasil uji $\mathrm{F}$ Hasil estimasi random effect didapatkan bahwa variable independent (X1 dan X2) signifikasi F hitung sebesar 77.53949 dengan Prob(Fstatistic) sebesar $0,00000<0,05$ lebih kecil dari taraf kesalahan 5\%. Hasil uji $\mathrm{F}$ membuktikan bahwa kedua variable independent berpengaruh signifikan terhadap variable dependent, dan hipotesis (H1) diterima yang artinya pertumbuhan ekonomi dan rata-rata lama sekolah berpengaruh signifikan terhadap kemiskinan di provinsi jawa tengah. Hasil penelitian ini sama dengan penelitian yang dilakukan oleh Subanidja \& Suharto (2013) di dalam jurnal internasional seni dan sains, humaniora dan ilmu sosial yang dilakukan di indonesia. Menghasilkan kesimpulan bahwa kemiskinan di indonesia dipengaruhi oleh pendidikan, HDI, pengangguran, PDRB, dan UMR. Serta penelitian yang dilakukan oleh Serta penelitian yang dilakukan oleh Anjuli \& Fitrayati (2011)dalam jurnal pendidikan ekonomi (JUPE) yang dilakukan di kabupaten sampang.yang menghasilkan kesimpulan bahwa pertumbuhan ekonomi, pendidikan dan pengangguran berpengaruh signifikan dalam penurunan kemiskinan.

\section{Pengaruh Pertumbuhan Ekonomi Terhadap Kemiskinan di Provinsi Jawa Tengah tahun 2009- 2018}

Berdasarkan tabel hasil uji $\mathrm{T}$ diketahui bahwa masing-masing variable bebas berpengaruh signifikan terhadap variable terikat. Pemgujian uji $\mathrm{T}$ (parsial) digunakan untuk perbandingan antara t hitung dan $\mathrm{t}$ tabel, pada umumnya taraf kesalahan yang digunakan penelitian kuantitatif adalah 5\% Nachrowi \& Usman (2006)Taraf kepercayaan /signifikansi yang dipakai adalah 95\%, dengan resiko meleset atau taraf kesalahan sebesar 5\%,
Pertumbuhan ekonomi Kabupaten/Kota (X1) Dengan Koefisien Regresi sebesar -0.210931 dan probabilitas $0.0052<0,05$ lebih kecil dari taraf kesalahan $5 \%$ jadi kesimpulanya variable pertumbuhan berpengaruh signifikan negatif terhadap variable kemiskinan. Penelitian ini menghasilkan koefisien regresi yang sama dengan teori trickle down effect Hirschman (1958) dimana pertumbuhan ekonomi akan berdampak terhadap kemiskinan secara tidak langsung, oleh adanya aliran vertikal dari penduduk kaya ke penduduk miskin. Serta hasil penelitian dari Mills \& Perenia (1993) bahwa kemiskinan akan mengalami penurunan saat pertumbuhan ekonomi tahun sebelumnya naik, apabila pertumbuhan PDB mengalami peningkatan terus menerus angka kemiskinan akan turun.

Pengaruh Rata-Rata Lama Sekolah Terhadap Kemiskinan di Provinsi Jawa Tengah tahun 2009-2018 Pendidikan/Rata-Rata Lama Sekolah (X2) dengan koefisien regresi sebesar -2.702.084 probabilitas $0.0000<0,050$ lebih kecil dari taraf kesalahan $5 \%$ jadi kesimpulanya variable Pendidikan (RLS) berpengaruh signifikan negatif terhadap variable kemiskinan. Penelitian ini menghasilkan koefisien regresi yang sama dengan teori Human Capital, teori ini mengasumsikan bahwa investasi dalam dunia pendidikan dapat memperbaiki kualitas produktifitas masyarakat, jika kualitas pendidikan baik maka kualitas masyarakatnya semakin baik, pendidikan dapat membuat seseorang keluar dari lingkaran kemiskinan. Penelitian ini mempunyai hasil yang sama dengan penelitian penelitian Suryandari (2017) Tahun 2004-2014. Penelitian tersebut membuktikan bahwa pendidikan berhubungan negatif dan berpengaruh signifikan terhadap kemiskinan. Hasil penelitian menunjukkan bahwa variable pendidikan yang dilihat dari partisipasi pendidikan tidak berpengaruh signifikan terhadap kemiskinan yang dilihat dari presentase penduduk miskin di Provinsi DKI Jakarta selama tahun 2009-2013 baik secara parsial maupun simultan.

\section{PENUTUP \\ Simpulan}

Dari penelitian ini dapat diperoleh kesimpulan sebagai berikut : (1) Pertumbuhan ekonomi (PDRB) dan Rata-rata lama Sekolah berpengaruh signifikan negatif terhadap kemiskinan tahun 2009-2018 di kabupaten kota di Jawa Tengah, (2) Pertumbuhan ekonomi (PDRB) berpengaruh signifikan negatif terhadap kemiskinan selama tahun 2008-2019 di kabupaten kota di Jawa Tengah, (3) Rata-rata lama sekolah berpengaruh signifikan negatif terhadap kemiskinan tahun 2009-2018 di kabupaten kota di Jawa Tengah, (4) pertumbuhan 
ekonomi dan Rata-Rata Lama Sekolah berpengaruh terhadap kemiskinan sebesar 30,8\% berdasarkan uji koefisien determinasi (R2)

\section{Saran}

Berdasarkan simpulan diatas dapat dijabarkan saran guna penelitian setelah ini adalah (1) pelaksanaan program-program yang dapat mengatasi permasalahan kemiskinan serta program peningkatan pertumbuhan ekonomi dan rata-rata lama sekolah di masyarakat, (2) untuk penelitian selanjutnya peneliti dapat menambah variable-variable lain dalam penelitian untuk memperjelas faktor yang nenpengaruhi kemiskinan di provinsi jawa tengah.

\section{DAFTAR PUSTAKA}

Anjuli, A. D., \& Fitrayati, D. (2011). Pengaruh Pertumbuhan Ekonomi, Pendidikan, dan Pengangguran Terhadap Kemiskinan di Kabupaten Sampang.

Bank, W. (1990). World Development.

Basuki, A. T., \& Prawoto, N. (2016). Analisis Regresi Dalam Penelitian Ekonomi \& Bisnis : Dilengkapi Aplikasi SPSS \& EVIEWS. PT Rajagrafindo Persada.

becker, gery. (1964). Human Capital. National Bureau of Economics Research.

BPS. (2008). Analisis dan Perhitungan Tingkat Kemiskinan Tahun 2008.

Cooray, A. (2009). The role of education in economic growth. 1-27.

Ghozali, I. (2013). Aplikasi Analisis Multivariate Dengan Program IBM SPSS 21 Update PLS Regresi (7th ed.). Badan Peneerbit Universitas Diponegoro.

Hirschman, A. otto. (1958). The Strategy Of Economic Development. Yale University Press.

Kuncoro, M. (2011). Metode Kuantitati. Sekolah Tinggi Ilmu Manajemen: YKPN.

Mankiw, \& Gregory. (2012). Pengantar Ekonomi Makro. Salemba Empat.

Mills, \& Perenia. (1993). Introduction and overview. In E.M. Pernia (Ed.), Urban Poverty in Asia: A Survey of Critical Issues. Oxford University Press.

Nachrowi, D., \& Usman, H. (2006). Pendekatan Populer dan Praktis Ekonometrika untuk Analisis Ekonomi dan Keuangan. Universitas Indonesia.
Nasution, Z. dan Hartono, T. T. (2007). Kondisi Sosial Budaya Masyarakat Nelayan. Urnal Sosial Dan Budaya.

Sastraatmadja E. (2003). Ekonomi Pertanian Indonesia Masalah. Angkasa.

Subanidja, S., \& Suharto, E. (2013). The Dominant Faktors In The Causes Of Poverty Levels In Indonesia. Humanities And Social Sciens, December.

Sugiyono. (2014). Metode Penelitian Pendidikan Pendekatan Kuantitatif, Kualitatif, dan R\&D. PT Alfabeta.

Sukirno, S. (2011). Makroekonomi Teori Pengantar (1st ed.). Rajawali Pers.

Sukirno, S. (2012). Makro Ekonomi Teori Pengantar Edisi Ketiga. Rajawali Pers.

Sumarsono, S. (2004). Metode Riset Sumber Daya Manusia. Graha Ilmu.

Suryandari, A. N. (2017). Pengaruh Pertumbuhan Ekoonmi, Pendidikan, dan Kesehatan Terhadap Tingkat Kemiskinan di daerah Istimewa Yogyakarta Tahun 2004-2014.

Wahyudi, D., \& Rejeningsih, T. W. (2013). Analisis Kemiskinan di Jawa Tengah. Diponegoro Journal of Economics, 2. 